ETHICAL ECOTOURISTS: THE NARWHAL DILEMMA REVISITED 


\title{
ETHICAL ECOTOURISTS: THE NARWHAL DILEMMA REVISITED
}

\section{Ralf Buckley}

Director International Centre for Ecotourism Research, Griffith University, Australia. Phone: 075552 8675, Fax: 075552 8895, E mail r.buckley@griffith.edu.au

\begin{abstract}
Studying the ethical philosophies of individual travellers is a valid field of research, but there are practical difficulties in defining an industry subsector in terms of the intentions of its customers. Concerns over the conservation of endangered species may conflict with equally principled concerns over the rights and responsibilities of Indigenous communities.
\end{abstract}

\section{Introduction}

Among the many conceptualisations of ecotourism (Buckley, 2003; Donohoe \& Needham, 2006; Weaver \& Lawton, 2007), there is one recent school of thought favouring a definition based on ethics (Fennell, 2004). Buckley (2005) used an ethical dilemma, referred to here as the narwhal dilemma, to argue that an ethics-based definition is operationally unrealistic. Malloy (2009, p. 73) presented a critique of that argument, on the grounds that ecotourism should be seen as 'A movement of humans in search of a better understanding of their place in the world', and that 'an ecotourist cannot be unethical if he or she truly values the tenets of ecotourism'. Here, I re-examine that critique and its application to the narwhal dilemma.

To recapitulate briefly, Buckley (2005) described a real-life scenario where a commercial multi-day Arctic sea kayak tour to watch narwhal first chartered an Inuit speedboat to shuttle them to a distant bay and later met the Inuit with tusks from several illegally killed narwhal. The dilemma was simply, what an ethically defined ecotourist should do under such circumstances. Malloy (2009) took issue with three components of Buckley's argument: the conclusion, that ecotourism cannot realistically be defined in ethical terms; a corollary, that some ecotourists may therefore be unethical; and an analogy, that we expect doctors to act ethically but do not define medicine in ethical terms. 
Malloy's position is not entirely clear but appears to contain the following components that: (1) ecotourism is an individual philosophy of travel, not an industry subsector; (2) the philosophy is to act ethically; (3) ethicality should be defined using a Kantian form of deontology; (4) the Kantian notion of ethicality is defined by intent; (5) a good intention in the Kantian sense corresponds to principled values in Hodgkinson's hierarchy of values; and (6) such values correspond to meditative rather than calculative thought sensu Heidegger. Malloy then argues that ecotourism can be distinguished from adventure tourism because in his view it: (a) involves meditative mental modes; (b) is therefore principled; (c) is therefore well-intentioned; (d) is therefore ethical; and (e) it is therefore ecotourism.

This argument contains the following logical deficiencies. Of the six numbered components above, the first two are merely personal assertions. Much of the ecotourism literature takes different perspectives (Weaver \& Lawton, 2007). The third component is an arbitrary choice, one of three main ethical schools and numerous subschools (Fennell, 2007). The fourth seems to be simply incorrect: while Kant did indeed discuss questions of intent, Kantian ethics are centred on the concept of the categorical imperative, a secular mental test that is defined by actions, not intentions. The fifth and sixth are unsupported assertions: the hierarchy of values put forward by Hodgkinson (1996) was derived from educational administration and is not linked either to the philosophies of Kant or Heidegger.

In addition to its logical deficiencies, Malloy's argument does nothing to resolve the narwhal dilemma. Insofar as we may be able to judge (a difficult issue in itself), the tourists had good intentions and a Kantian sense of duty towards both narwhal and Inuit, but these duties were in conflict. Similarly, values related to the conservation of endangered species and those related to self-determination rights of Indigenous peoples are both principled sensu Hodgkinson, but in the narwhal dilemma these values are in conflict. The literature on outdoor recreation indicates, through concepts such as flow (Csikszentmihalyi \& Csikszentmihalyi, 1990, cited in Fennell, 2002) and peak experience (Pomfret, 2006; Walle, 1997), that meditative mental states are at least as common in adventure as in ecotourism. In any case, in order to appreciate the sublime biological beauty of the narwhal, the tourists also had to paddle their sea 
kayaks through adventurous Arctic waves and waters - it was the same tour and the same experience.

Besides these philosophical and practical deficiencies, Malloy's argument also contains rather severe scholastic shortcomings. The perspective of local Inuit as described by Buckley (2005, pp. 131-132) was mistakenly attributed by Malloy (2009, p. 71) to the tour operator. Buckley (2005, pp. 132-133) set out his own impressions, values and actions, but Malloy (2009, p. 73) claimed incorrectly that he did not. Buckley (2005) asked readers to provide their own responses to the dilemma from a list of immediately feasible options; Malloy's response was a list of improbable heroics, irrelevant since the narwhal were already dead. Malloy (2009, p. 71) criticised concepts of pragmatism (LaFollette, 2000, 2007) and cash value (p. 71), but neither of these were mentioned at all by Buckley (2005). Malloy (2009, p. 73) also claimed incorrectly that Buckley (2005) had effectively suggested that 'because we travel under the label of ecotourism, all of us by virtue of this association automatically internalise the tenets of ecotourism as a mere moral cloak'. This is an internally contradictory statement, and one which Buckley (2005) did not in fact make.

The most critical stumbling block to Malloy's approach, however, is very simple. If we were to define ecotourists in terms of their intentions, assuming we could tell what those intentions were, then how would we decide what particular intentions were right or dutiful, except by referring to an objective definition of ecotourism? It might be possible, in theory, to construct a vast set of detailed instructions, based on a much-extended body of recreation ecology and social impact research, sufficient to define codes of best practice in all conceivable situations that any ecotourist might encounter; and then to argue, with dubious validity, that ethical behaviour corresponds to following these codes. Most codes of ecotourism practice currently in existence, however, are routinely ignored (Scarpaci \& Dayanthi, 2003). A code-based view of ecotourism ethics would, at least, be a position worthy of serious debate, but it is not the approach that Malloy (2009) proposes.

Given these difficulties, it does indeed appear unrealistic to define ecotourism in ethical terms. Therefore, it follows that unethical or amoral ecotourists can exist because morality is not the defining criterion for ecotourism. Similarly, unethical 
doctors can and do exist. They may be expelled from professional medical associations if they act unethically, but they are still doctors. This, presumably, is why hospitals hire specialists in medical ethics. Equally, there are accepted codes of ethical practice in research, and universities nominate appropriate staff as ethics advisors. An academic who breaches such codes, however, is still an academic; just an unethical one.

Malloy (2009) took particular issue with the analogy suggested by Buckley (2005) that doctors are expected to be ethical but medicine is not defined in ethical terms, but he cited only a specialist text in medical ethics. Dictionary definitions of medicine, i.e. those understood by our society at large, refer only to 'The art of restoring and preserving health' (Coulson, Carr, Hutchinson, \& Eagle, 1975) or 'The science and art dealing with the prevention, cure, or alleviation of disease' (Merriam \& Co, 1956). Neither of these mention ethics at all. Medical practitioners need ethics, certainly; but they also need knowledge, skill, equipment, and pharmaceuticals; and there is a large medical industry that trains and certifies doctors, insures patients, builds hospitals, and develops new drugs. Similarly, most ecotourists may well be ethical, but there is a large ecotourism industry that continues to exist even if some are not.

Attempts to define ecotourism on ethical grounds, therefore, remain elusive. A modern illustration is presented in the cartoon series Calvin and Hobbes, where the characters are named after two philosophers: one a deontologist and the other a teleologist (Watterson, 1992). There is one particular sequence where the cartoon Calvin (a 6-year-old boy) achieves a metaphysical conversion of a cardboard box into an ethicator, a device that duplicates only his good side so as to produce a superficially similar entity whom he calls 'Dupe'. It does not take long before Dupe, incensed by the attitudes of the original cartoon Calvin, decides to tear him limb from limb. Since this intention is in itself an evil thought and hence incompatible with this ethical make-up, however, it causes Dupe to self-destruct, leaving Calvin himself with the last word: 'My ethicator must have had a built-in moral compromise spectral phantasmatron'.

From a strictly logical sense, the arguments advanced by Buckley (2005) and Malloy (2009) are not at cross purposes: they are completely independent. There is no point of contact between the argument that for ethical reasons, ecotourism ought to be 
defined in ethical terms; and the argument that for pragmatic reasons, it is more useful to define ecotourism in pragmatic terms. For a researcher who studies the effects of tourism on the environment, it is ethical as well as pragmatic to define ecotourism according to observable criteria. For a researcher who uses the behaviour of tourists as a case study in human ethics, it is pragmatic as well as ethical to define ecotourism in terms of individual intent.

There is no logical inconsistency in the suggestion that ecotourism can be defined without reference to ethical criteria, while still expecting ecotourists to behave in an ethical manner. This distinction allows economic statisticians to calculate the scale of the ecotourism sector, while still permitting ethics researchers to examine the ethics of individual ecotourists. There is thus no reason why these two lines of enquiry cannot continue in parallel. We cannot expect that ecotourism researchers will all turn their attention to ethics. Some at least will adopt the approach expressed by cartoon Calvin's alter ego Tracer Bullet (Watterson, 1992, p. 111): 'I always leave when the talk gets philosophical'.

\section{References}

Buckley, R.C. (2003). Environmental inputs and outputs in ecotourism geotourism with a positive triple bottom line? Journal of Ecotourism, 2(1), 76-82.

Buckley, R.C. (2005). In search of the narwhal: Ethical dilemmas in ecotourism. Journal of Ecotourism, 4(2), 129-134.

Coulson, J., Carr, C.T., Hutchinson, L., \& Eagle, D. (1975). The Oxford illustrated dictionary (2nd edn). London: Oxford University Press.

Csikszentmihalyi, M., \& Csikszentmihalyi, I.S. (1990). Adventure and the flow experience. In J.C. Miles \& S. Priest (Eds.), Adventure education (pp. 149-156). State College, PA: Venture.

Donohoe, H.M., \& Needham, R.D. (2006). Ecotourism: The evolving contemporary definition. Journal of Ecotourism, 5(3), 192-210. 
Fennell, D.A. (2002). Ecotourism programme planning. Wallingford, UK: CAB International.

Fennell, D.A. (2004). Deep ecotourism: Seeking theoretical and practical reverence. In T.V. Singh (Ed.), New horizons in tourism: Strange experiences and stranger practices (pp. 109-121). Wallingford, UK: CABI Publishing.

Fennell, D.A. (2007). Tourism ethics. Clevedon, UK: Channel View.

Hodgkinson, C. (1996). Administrative philosophy. Oxford, UK: Pergamon.

LaFollette, F. (2000). Pragmatic ethics. In H. LaFollette (Ed.), Blackwell guide to ethical theory (pp. 400-419). Oxford, UK: Wiley-Blackwell.

LaFollette, H. (2007). The practice of ethics. Oxford, UK: Wiley-Blackwell.

Malloy, D.C. (2009). Can one be an unethical ecotourist? A response to R. Buckley’s 'in search of the narwhal'. Journal of Ecotourism, 8(1), 70-73.

Merriam, G., \& Co, C. (1956). Webster's new collegiate dictionary. Springfield, MA: Merriam.

Pomfret, G. (2006). Mountaineering adventure tourists: A conceptual framework for research. Tourism Management, 27(1), 113-123.

Scarpaci, C., \& Dayanthi, N. (2003). Compliance with regulations by swim-withdolphins operations in Port Phillip Bay, Victoria, Australia. Environmental Management, 31(3), 342-347.

Walle, A.H. (1997). Pursuing risk or insight? Marketing adventures. Annals of Tourism Research, 24(2), 265-282.

Watterson, B. (1992). Attack of the deranged mutant killer monster snow goons (pp. 118-122). Kansas, MO: Universal. 
Weaver, D.B., \& Lawton, L.J. (2007). Twenty years on: The state of contemporary ecotourism research. Tourism Management, 28(5), 1168-1179. 